\title{
PHENOTYPE VARIABILITY AND INHERITANCE OF PLANT HEIGHT AND BRANCHING IN F 1 GENERATION OF SUNFLOWER
}

\author{
Terzić, S. ${ }^{*}$ Zorić, M., Miladinović, F. \\ Institute of Field and Vegetable Crops, Maksima Gorkog 30., \\ 21000 Novi Sad, Serbia
}

Received: September 10, 2005 Accepted: March 25, 2006

\section{SUMMARY}

Highly variable populations of wild sunflower species were crossed with CMS cultivated lines. Variability was determined by measuring plant height and evaluating the type of branching. Mode of inheritance was tested by comparing the 27 hybrid populations against parents. Differences among parents in the observed traits were significant. All modes of inheritance for plant height were present in the $F_{1}$ generation. Heterosis was most frequent, followed in decreasing order by partial dominance, dominance and intermediacy. More than one mode of inheritance for plant height occurred because of the large variability in wild species and poligenic inheritance of the characteristic. All $\mathrm{F}_{1}$ populations were fully branched, with or without the central head. The wild type of branching was found in $F_{1}$ because the wild parent dominated in genetic control of that trait over the cultivated one.

Key words: sunflower, wild species, interspecies hybridization, variability, plant height, inheritance, branching

\section{INTRODUCTION}

There are seven annual and 22 perennial species of wild sunflowers in the collection of Novi Sad Oilcrops Department. They are used because of high variability that has been confirmed by the cluster analysis of morphological characters (Schiling and Heiser, 1981), which also showed phylogenetic relationships inside the Helianthus genus. Plant height and branching are important characters in sunflower production because they can have large influence on seed yield. The use of wild species in sunflower breeding increases the variability of those traits and often results in branched $F_{1}$ plants. The goal of this study was to define the variability of

* Corresponding author, Phone: +381 214898 429, Fax: +38121413 833, e-mail: terzic@ifvcns.ns.ac.yu 
the tested traits and the mode of inheritance for plant height. That was done through hybridization of cultivated inbred lines with populations of wild sunflower.

\section{MATERIALS AND METHODS}

Seven annual and sixteen perennial populations have been used for hybridization. Pollen from wild species has been applied to the inflorescences of cultivated cytoplasmatic male sterile sunflower.

All $F_{1}$ and parent populations were measured for plant height and the obtained data were used for calculating mean values, standard deviations and variation coefficients. The mode of inheritance was determined by testing the significance of differences between mean values of $\mathrm{F}_{1}$ generations and parent populations (Borojević, 1965).

The type of branching was evaluated by using the sunflower descriptors (IBPGR, 1985). There are five types of branching described:

0 -no branching,

1 -basally branched,

2 -top branched,

3 -fully branched with a central head and

4 -(wild type) fully branched without a central head (Figure 1).
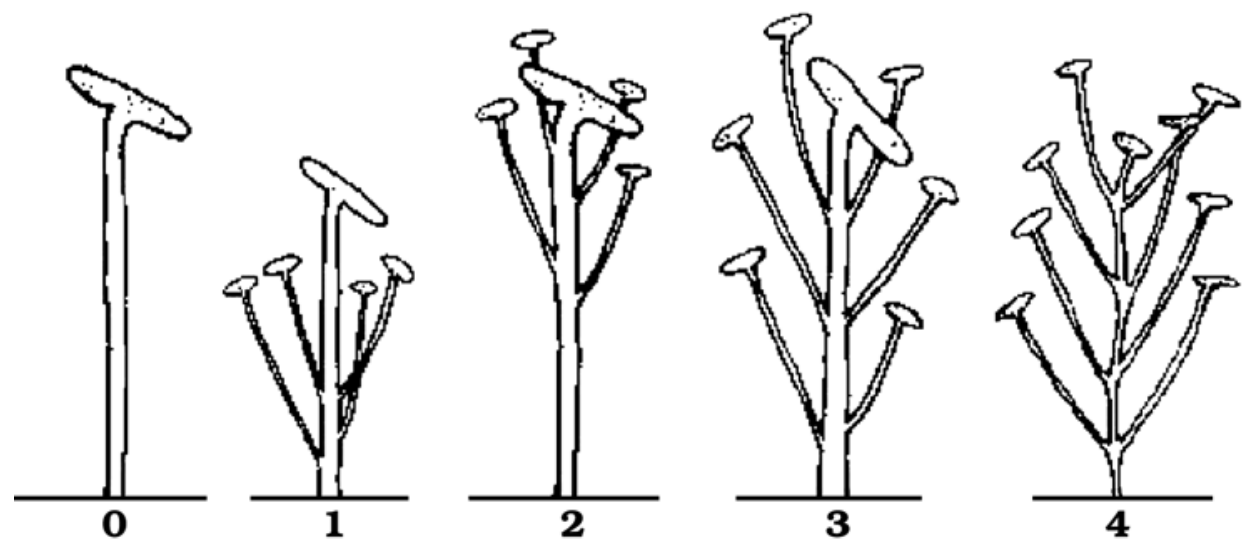

Figure 1: Types of branching

\section{RESULTS}

All modes of inheritance for plant height were registered. The most frequent was heterosis (11/27) followed by partial dominance (6/27) and dominance (5/27). Intermediate mode of inheritance and dominance of cultivated sunflower was noted in two hybrid combinations each (Table 1). 
Ten populations of $H$. annuus were crossed with cultivated lines. In four out of eleven $\mathrm{F}_{1}$ hybrid combinations dominance of wild parent was noted. Positive heterosis was equally frequent. No significant differences between parents or between parents and the $F_{1}$ generation were found in the hybrid combination HA26A $\times$ ANN2188.

Populations of tetraploid perennial $H$. divaricatus had the same mean height as the cultivated line they were crossed with $(90 \mathrm{~cm})$. The mean height in the $\mathrm{F}_{1}$ generation was 140 and $150 \mathrm{~cm}$. Positive heterotic effects were found in both hybrid combinations (Figure 2). Intermediate mode of inheritance was found in two hybrid combinations, PHBC1 214A × ARG1805 and HA26A $\times$ LAE1618.

Table 1: Hybrid combinations, basic statistics and modes of inheritance

\begin{tabular}{|c|c|c|c|c|c|c|}
\hline \multirow{2}{*}{ Hybrid combination } & \multicolumn{3}{|c|}{ Plant height $(X \pm S x \mathrm{~cm})$} & \multirow{2}{*}{\multicolumn{2}{|c|}{$S D(F 1) C V \quad(F 1)$}} & \multirow{2}{*}{ I.* } \\
\hline & Cultivated line & $\mathrm{F}_{1}$ & Wild population & & & \\
\hline HA26A $\times$ ANN2129 & $90 \pm 1.11$ & $90 \pm 1.70$ & $100 \pm 1.70$ & 7.21 & 2.5 & $d^{c}$ \\
\hline HA26A $\times$ ANN2141 & $90 \pm 1.11$ & $100 \pm 2.46$ & $100 \pm 2.46$ & 8.82 & 2.8 & $d^{w}$ \\
\hline $\mathrm{HA} 26 \mathrm{~A} \times \mathrm{ANN} 2155$ & $90 \pm 1.11$ & $119 \pm 2.16$ & $120 \pm 2.16$ & 6.46 & 1.9 & $d^{w}$ \\
\hline HA26A $\times$ ANN2157 & $90 \pm 1.11$ & $110 \pm 0.83$ & $100 \pm 0.83$ & 6.78 & 1.9 & $\mathrm{~h}$ \\
\hline $\mathrm{HA} 26 \mathrm{~A} \times \mathrm{ANN} 2159$ & $90 \pm 1.11$ & $120 \pm 2.24$ & $95 \pm 2.24$ & 6.62 & 1.8 & $\mathrm{~h}$ \\
\hline $\mathrm{HA} 26 \mathrm{~A} \times \mathrm{ANN} 2180$ & $90 \pm 1.11$ & $150 \pm 1.96$ & $170 \pm 1.96$ & 8.80 & 1.9 & $\mathrm{pd}^{\mathrm{w}}$ \\
\hline HA26A $\times$ ANN2188 & $90 \pm 1.11$ & $85 \pm 1.97$ & $90 \pm 1.97$ & 5.46 & 2.0 & - \\
\hline PHBC1 190A $\times$ ANN2159 & $75 \pm 2.36$ & $73 \pm 2.24$ & $95 \pm 2.24$ & 25.52 & 11.1 & $d^{c}$ \\
\hline $\mathrm{PHBC} 1210 \mathrm{~A} \times \mathrm{ANN} 2165$ & $55 \pm 1.69$ & $130 \pm 1.91$ & $120 \pm 1.91$ & 9.85 & 2.4 & $d^{w}$ \\
\hline PHBC1 188A $\times$ ANN1963 & $95 \pm 1.63$ & $119 \pm 1.45$ & $50 \pm 1.45$ & 19.73 & 5.2 & $\mathrm{~h}$ \\
\hline $\mathrm{PHBC} 1213 \mathrm{~A} \times \mathrm{ANN} 2165$ & $60 \pm 1.39$ & $150 \pm 1.91$ & $120 \pm 1.91$ & 7.87 & 1.7 & $\mathrm{~h}$ \\
\hline PHBC1 203A $\times$ ARG1812 & $75 \pm 2.36$ & $150 \pm 1.25$ & $180 \pm 1.25$ & 8.87 & 1.9 & $\mathrm{pd}^{\mathrm{w}}$ \\
\hline PHBC1 202A $\times$ ARG1812 & $70 \pm 1.70$ & $160 \pm 3.04$ & $180 \pm 1.25$ & 9.61 & 1.9 & $\mathrm{pd}^{\mathrm{w}}$ \\
\hline PHBC1 214A $\times$ ARG1805 & $70 \pm 1.70$ & $170 \pm 1.83$ & $250 \pm 1.83$ & 10.96 & 2.0 & i \\
\hline PHBC1 212A $\times$ DEB1810 & $60 \pm 1.39$ & $120 \pm 1.89$ & $120 \pm 1.89$ & 11.08 & 1.7 & $d^{w}$ \\
\hline PHBC1 193A $\times$ PET1910 & $120 \pm 2.0$ & $170 \pm 2.29$ & $180 \pm 2.29$ & 8.04 & 1.5 & $\mathrm{pd}^{\mathrm{w}}$ \\
\hline HA26A $\times$ PET1383 & $90 \pm 1.11$ & $120 \pm 1.69$ & $130 \pm 1.69$ & 8.83 & 2.3 & $\mathrm{pd}^{\mathrm{w}}$ \\
\hline HA26A $\times$ PET2122 & $90 \pm 1.11$ & $110 \pm 1.83$ & $90 \pm 1.83$ & 8.93 & 2.6 & $\mathrm{~h}$ \\
\hline HA26A $\times$ NEG1181 & $90 \pm 1.11$ & $150 \pm 1.38$ & $120 \pm 1.38$ & 8.87 & 1.9 & $\mathrm{~h}$ \\
\hline HA26A $\times$ TUB6 & $90 \pm 1.11$ & $125 \pm 3.06$ & $110 \pm 3.06$ & 13.70 & 4.0 & $d^{w}$ \\
\hline HA26A $\times$ TUB20 & $90 \pm 1.11$ & $115 \pm 2.24$ & $95 \pm 2.24$ & 7.82 & 2.1 & $\mathrm{~h}$ \\
\hline HA26A $\times$ TUB1698 & $90 \pm 1.11$ & $170 \pm 2.11$ & $110 \pm 2.11$ & 16.41 & 3.5 & $\mathrm{~h}$ \\
\hline HA26A $\times$ DIV2056 & $90 \pm 1.11$ & $150 \pm 1.48$ & $85 \pm 1.48$ & 9.37 & 2.1 & $\mathrm{~h}$ \\
\hline HA26A $\times$ DIV2085 & $90 \pm 1.11$ & $140 \pm 1.49$ & $95 \pm 1.49$ & 8.50 & 1.9 & $\mathrm{~h}$ \\
\hline HA26A $\times$ STR1927 & $90 \pm 1.11$ & $105 \pm 2.08$ & $115 \pm 2.08$ & 9.49 & 2.2 & $\mathrm{pd}^{\mathrm{w}}$ \\
\hline HA26A $\times$ STR1623 & $90 \pm 1.11$ & $140 \pm 2.83$ & $90 \pm 2.83$ & 9.02 & 1.9 & $\mathrm{~h}$ \\
\hline HA26A $\times$ LAE1618 & $90 \pm 1.11$ & $110 \pm 2.36$ & $150 \pm 2.36$ & 6.86 & 2.2 & $\mathrm{i}$ \\
\hline
\end{tabular}

$$
\text { LSD } 5 \%=6.81 \quad \text { LSD } 1 \%=8.96
$$

*Inheritance modes: i-intermediate, h-heterosis, $\mathrm{pd}^{\mathrm{c}}$-partial dominance of cultivated sunflower, $\mathrm{d}^{\mathrm{W}}$-dominance of wild sunflower, $\mathrm{d}^{\mathrm{c}}$-dominance of cultivated sunflower 


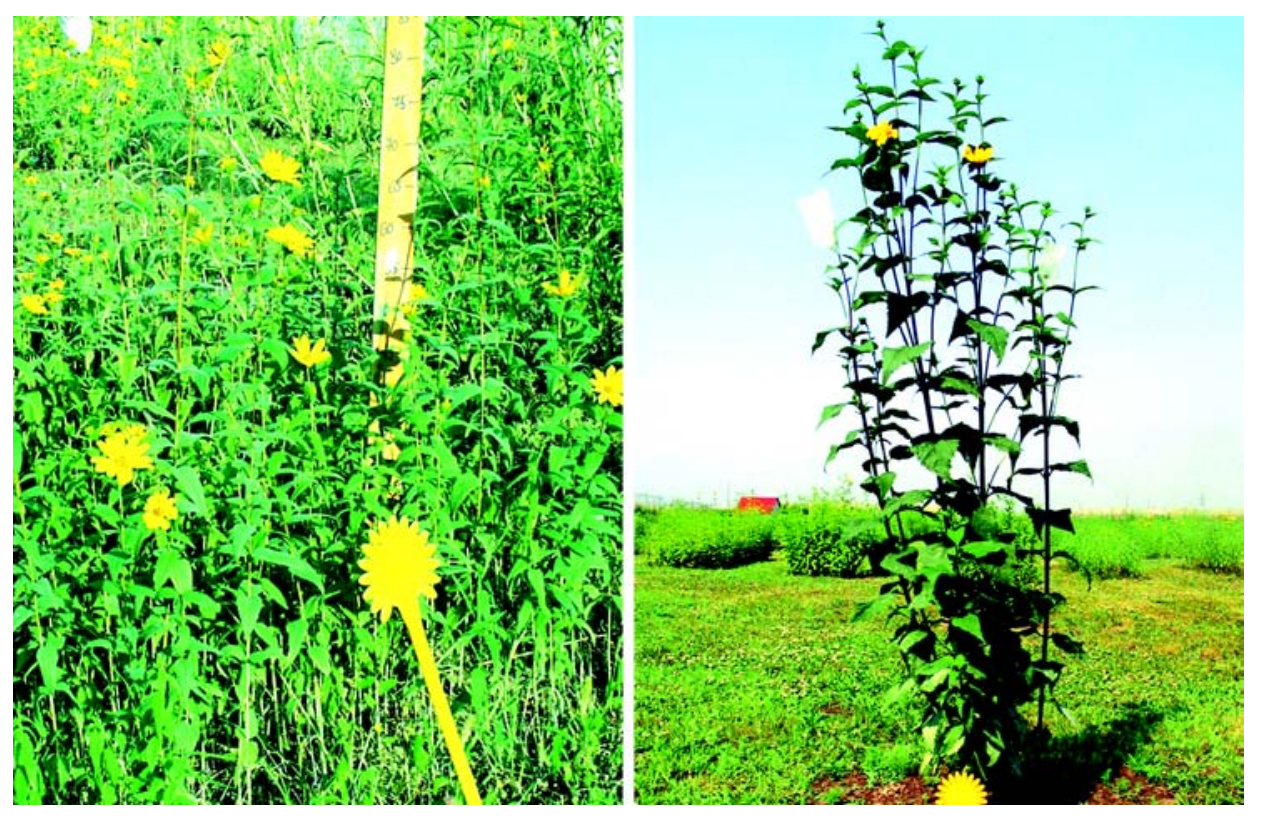

Figure 2: Wild population DIV2085 and $F_{1}$ hybrid with cultivated sunflower
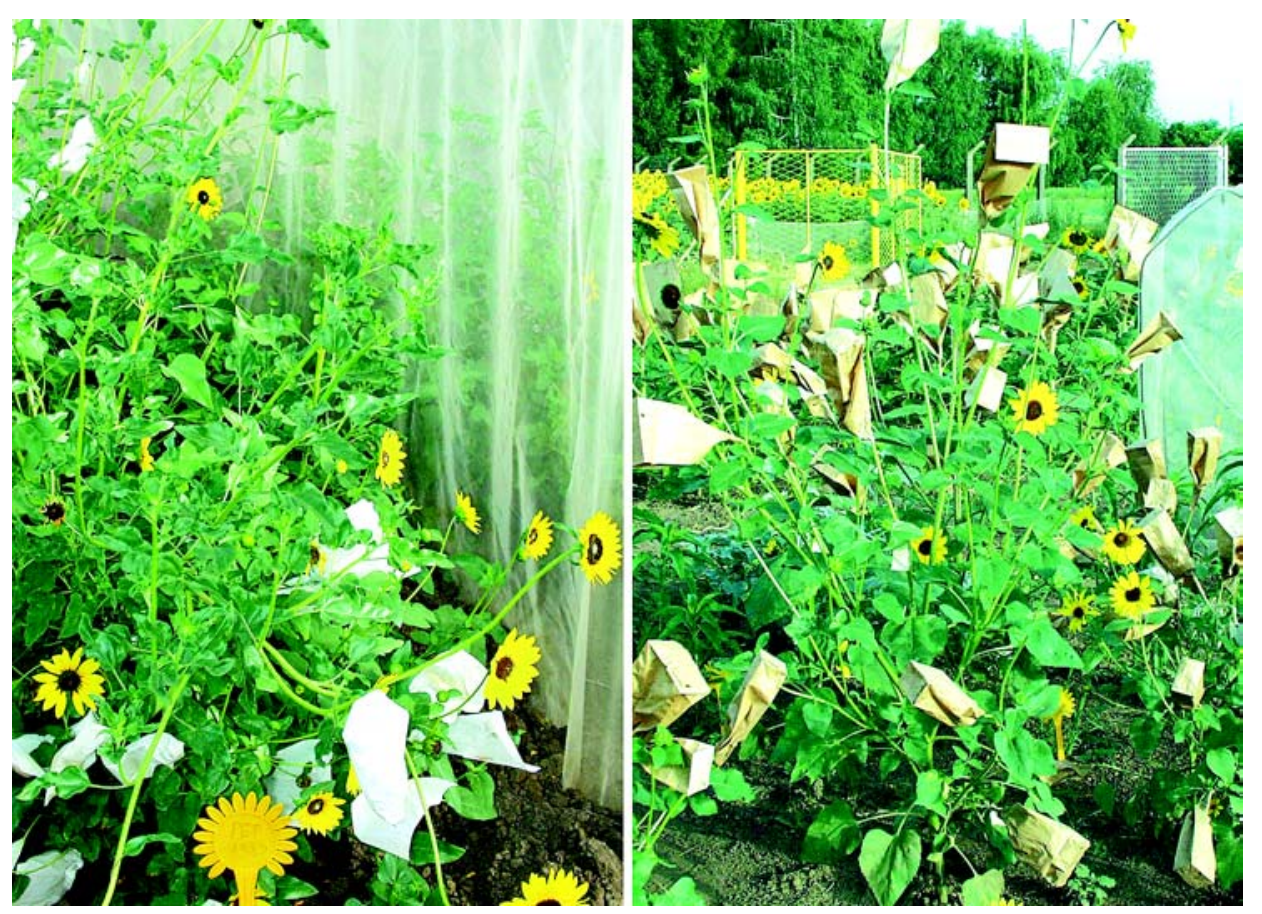

Figure 3: Wild population PET1383 and $F_{1}$ hybrid with cultivated sunflower 
Cultivated lines were not branched except for the populations PHBC1 202A and PHBC1 203A, in which plants with basal branching were found. Six out of seven hybrid combinations with $H$. annuus, in which non-branched plants were crossed with the wild branching type, resulted in fully branched plants with central heads.

Both populations of annual species $H$. argophyllus that were crossed with cultivated lines had the wild type of branching. All types of branching were found in the hybrid combination PHBC1 202A $\times$ ARG1812. The most frequent were fully branched plants, with or without the central head. Most of the plants in the other two hybrid combinations were fully branched with the central head (Table 2).

Table 2: Types of branching in $\mathrm{F}_{1}$ hybrid combinations with annual species

\begin{tabular}{|c|c|c|c|}
\hline \multirow{2}{*}{ Hybrid combination } & \multicolumn{3}{|c|}{ Type of branching } \\
\hline & Cultivated line & $\mathrm{F}_{1}$ & Wild population \\
\hline HA26A $\times$ ANN2129 ts11 & 0 & $1^{6}, 3^{4}$ * & 4 \\
\hline $\mathrm{HA} 26 \mathrm{~A} \times \mathrm{ANN} 2141$ ts 13 & 0 & $3^{8}, 4^{2}$ & 4 \\
\hline $\mathrm{HA} 26 \mathrm{~A} \times \mathrm{ANN} 2155$ ts 10 & 0 & $1^{5}, 0^{3}, 3^{2}$ & 3 \\
\hline HA26A $\times$ ANN2157 ts8 & 0 & $1^{4}, 3^{4}, 2^{1}, 0^{1}$ & $3^{7}, 4^{3}$ \\
\hline HA26A $\times$ ANN2159 ts6 & 0 & $3^{7}, 4^{2}, 1^{1}$ & $4^{8}, 3^{2}$ \\
\hline HA26A $\times$ ANN2180 ts25 & 0 & $3^{7}, 4^{3}$ & 3 \\
\hline HA26A × ANN2188 ts7 & 0 & $3^{9}, 4^{1}$ & 4 \\
\hline PHBC1 190A $\times$ ANN2159 ts1 & 0 & $3^{4}, 1^{3}, 4^{2}, 0^{1}$ & $4^{8}, 3^{2}$ \\
\hline PHBC1 $210 \mathrm{~A} \times$ ANN2165 ts3 & 0 & 3 & 4 \\
\hline PHBC1 188A $\times$ ANN1963 ts20 & 0 & $3^{5}, 1^{3}, 4^{2}$ & 4 \\
\hline PHBC1 213A $\times$ ANN2165 ts22 & 0 & 3 & 4 \\
\hline PHBC1 203A × ARG1812 ts4 & $0,1^{1}$ & $3^{6}, 1^{3}, 4^{1}$ & 4 \\
\hline PHBC1 202A $\times$ ARG1812 ts21 & $0^{5}, 1^{5}$ & $4^{4}, 3^{3}, 1^{1}, 0^{1}, 2^{1}$ & 4 \\
\hline PHBC1 214A $\times$ ARG1805 ts18 & 0 & $3^{8}, 2^{1}, 1^{1}$ & 4 \\
\hline PHBC1 212A × DEB1810 & 0 & $4^{6}, 3^{4}$ & 4 \\
\hline PHBC1 193A × PET1910 & 0 & 4 & 4 \\
\hline $\mathrm{HA} 26 \mathrm{~A} \times \mathrm{PET} 1383$ & 0 & $3^{7}, 4^{3}$ & 4 \\
\hline HA26A $\times$ PET2122 & 0 & 4 & 4 \\
\hline $\mathrm{HA} 26 \mathrm{~A} \times \mathrm{NEG} 1181 \mathrm{ts} 12$ & 0 & $4^{8}, 3^{2}$ & 4 \\
\hline
\end{tabular}

${ }^{\star} 1^{6}, 3^{4}$ six plants with basal branches and four fully branched with central inflorescence.

Table 3: Types of branching in $\mathrm{F}_{1}$ hybrid combinations with perennial species

\begin{tabular}{lccc}
\hline \multirow{2}{*}{ Hybrid combinations } & \multicolumn{3}{c}{ Type of branching } \\
\cline { 2 - 4 } & Cultivated line & $\mathrm{F}_{1}$ & Wild population \\
\hline HA26A $\times$ TUB6 & 0 & $3^{8}, 4^{2}$ & 2 \\
HA26A × TUB20 & 0 & $3^{9}, 4^{1}$ & $2^{8}, 0^{2}$ \\
HA26A × TUB1698 & 0 & $3^{9}, 4^{1}$ & $2^{7}, 0^{3}$ \\
HA26A $\times$ DIV2056 & 0 & $3^{9}, 4^{1}$ & $2^{8}, 1^{2}$ \\
HA26A $\times$ DIV2085 & 0 & $3^{9}, 4^{1}$ & $2^{9}, 1^{1}$ \\
HA26A $\times$ STR1623 & 0 & $3^{9}, 4^{1}$ & $2^{8}, 0^{2}$ \\
HA26A $\times$ STR1927 & 0 & 3 & 2 \\
HA26A $\times$ LAE1618 & 0 & $4^{6}, 3^{3}, 1^{1}$ & 2 \\
\hline
\end{tabular}


Three populations of the annual species $H$. petiolaris were crossed with the lines of cultivated sunflower. Wild populations were fully branched without the central head. All plants in the hybrid combination HA26A $\times$ PET1383 were fully branched. There were seven plants with the central head and three without it (Figure 3.). Plants from the other two $\mathrm{F}_{1}$ hybrid combinations had the wild type of branching.

Three populations of the perennial hexaploid species $H$. tuberosus were crossed with cultivated lines of sunflower. All three were top branched. Nonbranched plants were found in populations TUB20 and TUB1698. A similar type of branching was found in all other populations of perennial species used. It is likely that plants had such type of branching because of population density and plant competition. In the $F_{1}$ generation, most of the plants were completely branched with central heads (Table 3.).

\section{DISCUSSION}

Plant height shows continuous variability in accordance with the normal distribution of frequencies. Such variability is due to a large number of genes that control that trait. More than one mode of inheritance occurred because of large variability in the wild species and quantitative inheritance of that trait (Marinković, 1982). Because of that, determination of the mode of inheritance was influenced by genetic differences between parents as well as by interactions with the environment.

The mean value differences between the parents in majority of the hybrid combinations were significant. Plant height among the wild species varied from $50 \mathrm{~cm}$ (ANN1963) to $250 \mathrm{~cm}$ (ARG1805). Within-species variability was also significant (50-170 cm, H. annuus). Such results confirm a large variability of the wild species (Rogers et al., 1982).

All modes of inheritance for plant height were registered (heterotic, dominant, partially dominant and intermediary). Heterosis was most frequent in the $\mathrm{F}_{1}$ hybrid populations. That is similar to the results of Ananjeva (1936), Morozov (1947), and other authors. Occurrence of heterosis shows that there were epistatic interactions between the mentioned genotypes. Plant height was under dominant or partially dominant influence of wild parent in half of the $F_{1}$ hybrid combinations. Heiser, (1951, 1955), Georgieva (1976) and other authors found such modes of inheritance in crosses between wild and cultivated sunflowers.

Dominant and recessive genes control the inheritance of branching (Miller and Fick, 1997). Two complementary dominant genes are reported to control the branching in wild species (Hocket and Knowles, 1970; Fernandez-Martinez and Knowles, 1982; Kovacik and Skaloud, 1990). Type of branching depends on the presence of different genes $\left(\mathrm{Br}_{-} \mathrm{Br}_{3}\right)$ and their interactions. The wild type of branching is most frequent. Recessive genes (b1-b3) can also control branching. They are often incorporated in fertility restorer lines to obtain top branching.

All $F_{1}$ interspecies hybrid populations obtained in this study were fully branched with or without the central head. The wild type of branching was frequent in the $F_{1}$ generation because the wild parents had dominant influence over that 
trait. It is necessary to perform further crosses with the cultivated lines for determination of the mode of inheritance. Non-branched interspecies hybrids can be obtained through backcrossing with cultivated lines and negative selection for branching.

\title{
REFERENCES
}

Ananjeva, S. V., 1936. Gibridologičeskij analiz nekotorih priznakov podsolnečnika Sb.Fiz.stajkost ozimih i jarovih hlebov i podsolnečnika, Moskva, pp. 160-176.

Borojević S., 1965. Način nasleđivanja i heritabilnost kvantitativnih svojstava u ukrštanjima raznih sorti pšenice. Savremena poljoprivreda, Novi Sad, br. 7-8: 587-605.

Georgieva-Todorova, J., 1976. Interspecific relationships within the genus Helianthus (in Bulgarian). Bulgarian Academy of Sciences, Sofia.

Fernandez-Martinez, J., and P. F. Knowles, 1982. Genetica de la polifloria en el girasol silvestre Helianthus annuus L. Anal. Instit. Nacional Invest. Agrarias Ser. Agricola 17: 25-30.

Heiser, Ch.B., 1951. Hybridization in the Annual Sunflowers: Helianthus annuus $\times H$. argophyllus. The American Naturalist, Vol. LXXXV, No. 820: 64-72.

Heiser, Ch.B., 1955. Hybridization in the Annual Sunflowers: Helianthus annuus $\times$ H. debilis var. cucumerifolius. Evolution 5: 42-51.

Hockett, E. A., and Knowles, P. F., 1970. Inheritance of branching in sunflowers, Helianthus annuus L. Crop Sci. 10: 432-436.

IBPGR 1985. Descriptors for cultivated and wild sunflower. AGPG, /85/54, ROME.

Kovačik, A., and Škaloud, V., 1990. Results of inheritance evaluation of agronomically important traits in sunflower. Helia, 13(13): 41-46.

Marinković R., 1982. Inheritance of plant height and leaf number in diallel crossings of sunflower inbreds. In: Proc. 10 ${ }^{\text {th }}$ Int. Sunflower Conf., Surfers Paradise, Australia. 1418 Mar., Int. Sunflower Assoc., Paris, France pp. 232-233.

Miller J., and Fick G., 1997. The genetics of sunflower. P.441-495. In: A. A. Schneiter (ed.) Sunflower Technology and Production. Agron. Monogr. No 35., CSSA, Madison, WI.

Morozov, V. K., 1947. Selekcija podsolnečnika na uro_ajnost. Selekcija i semenovodstvo, 18-25.

Rogers, Ch. E., Thompson, T. E., Seiler, G. J., 1982. Sunflower Species of the United States. Nat. Sunflower Assoc., Fargo, ND.

Schiling E. E., Heiser, Ch. B., 1981. Infrageneric classification of Helianthus (Compositae). Taxon. 30(2): 393-403.

\section{VARIABILIDAD FENOTÍPICA Y HERENCIA DE ALTURA DE LA PLANTA Y DE RAMIFICACIÓN EN LA GENERACIÓN F1 DE GIRASOL}

\author{
RESUMEN
}

Las poblaciones de alta variabilidad de las especies silvestres de girasol, fueron cruzadas con las líneas cms cultivadas. La variabilidad fue determinada por medición de altura de las plantas y por calificación del tipo de ramificación. El modo de herencia fue ensayado por comparación de 27 poblaciones híbridas y sus progenitores. Las diferencias entre los progenitores, en el sentido de las características consideradas, fueron significantes. Todos los modos de la herencia de altura de la planta, estaban presentes en la generación $\mathrm{F}_{1}$. El más frecuente era el heterosis, seguido por una dominación parcial, dominación e intermediaridad. Más de un modo de la herencia de altura de la planta, se ha presentado por causa de una gran variabilidad de las especies silvestres y la herencia polígena de esta propiedad. Todas las poblaciones $\mathrm{F}_{1}$ eran completamente ramificadas, con el capítulo central, o sin él. El tipo de ramificación silvestre fue encontrado en la generación $\mathrm{F}_{1}$, porque el progenitor 
campestre era dominante en el control genético de la propiedad, respecto al progenitor cultivado.

\title{
VARIABILITÉ PHÉNOTYPIQUE ET HÉRÉDITÉ DE LA HAUTEUR DE LA PLANTE ET DE LA RAMIFICATION DANS LA GÉNÉRATION F 1 DU TOURNESOL
}

\author{
RÉSUMÉ
}

Des populations hautement variables d'espèces de tournesol sauvage ont été croisées avec des lignées cultivées CMS. La variabilité a été déterminée par la mesure de la hauteur de la plante et l'évaluation du type de ramification. Le mode d'hérédité a été testé par une comparaison de 27 hybrides avec leurs parents. Pour les caractéristiques observées, les différences parmi les parents observés étaient significatives. Tous les modes d'hérédité de la hauteur de la plante étaient présents dans la génération $\mathrm{F}_{1}$. L'hétérosis était le plus fréquent, suivi en ordre décroissant par la dominance partielle, la dominance et l'intermédiarité. À cause de la grande variabilité de l'espèce sauvage et de l'hérédité polygénique de la caractéristique, plus d'un mode d'hérédité pour la hauteur de la plante est apparu. Toutes les populations $F_{1}$ étaient pleinement ramifiées avec ou sans tête centrale. Le type sauvage de ramification se trouvait en $F_{1}$ parce que le parent sauvage dominait le parent sauvage pour le contrôle génétique de cette caractéristique. 